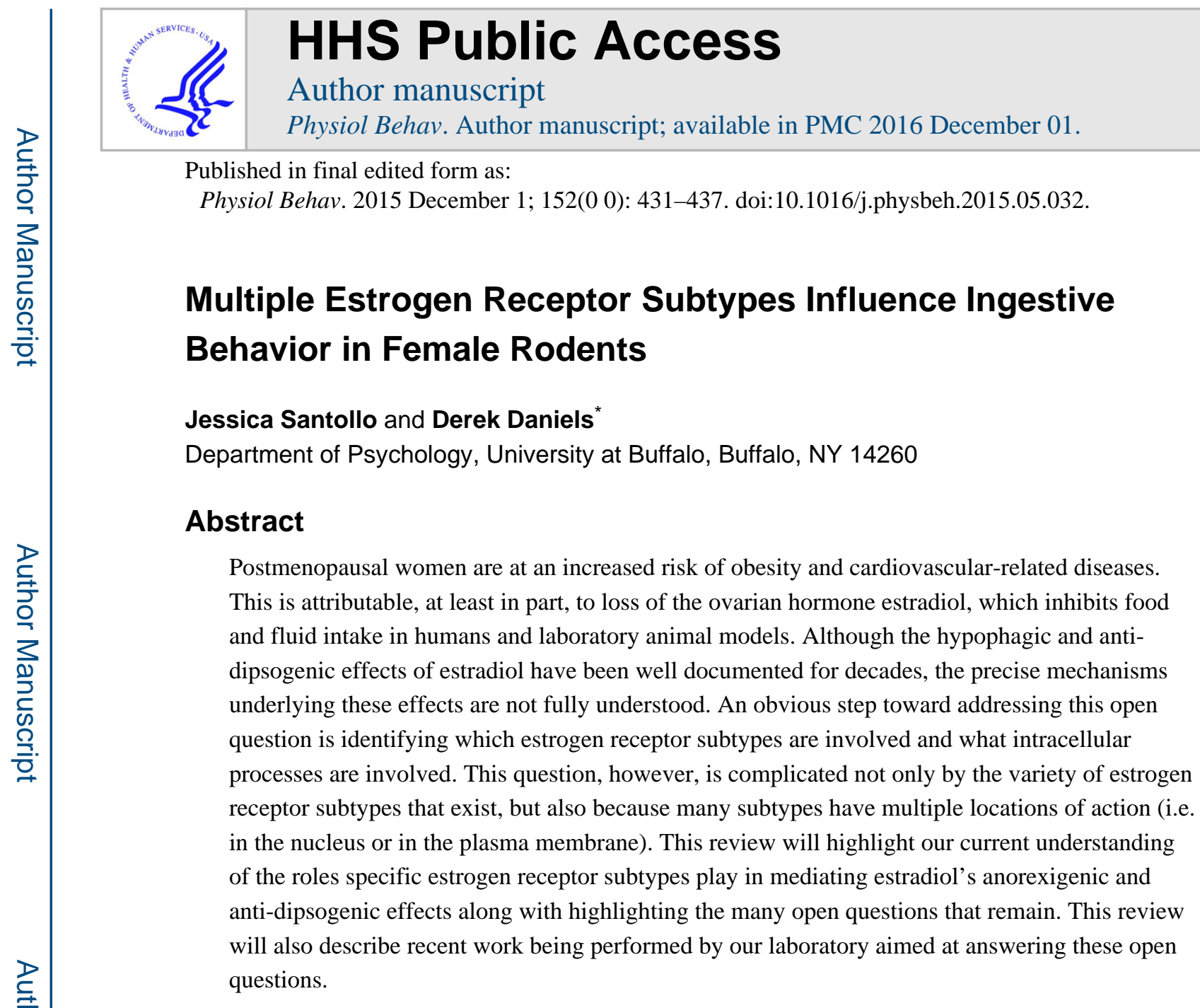

Keywords

Estradiol; food intake; water intake; saline intake

\title{
I. Background
}

Obesity rates have dramatically increased over recent decades and cardiovascular disease is the most common cause of death for women over the age of 65 in the United States [1,2]. While environmental factors likely play an important role in these trends, hormonal changes in older women also contribute to obesity and cardiovascular disease. Estrogens, specifically estradiol, have an inhibitory influence on food, water, and saline intakes in a variety of species, including humans [3, 4]. After surgical or natural hormone withdrawal, food, water, and saline intakes significantly increase [5,6]. Clinically, this is problematic because increased food intake is a risk factor for obesity, and increased water and saline intake can

\footnotetext{
*Correspondence and Reprint Request to: Derek Daniels, Department of Psychology, University at Buffalo SUNY, Buffalo, NY 14260, United States. Tel.: 716-645-0264; Fax: 716-645-3801; danielsd@ buffalo.edu.

Disclosures: none

Publisher's Disclaimer: This is a PDF file of an unedited manuscript that has been accepted for publication. As a service to our customers we are providing this early version of the manuscript. The manuscript will undergo copyediting, typesetting, and review of the resulting proof before it is published in its final citable form. Please note that during the production process errors may be discovered which could affect the content, and all legal disclaimers that apply to the journal pertain.
} 
disturb the delicate fluid balance that is needed to maintain healthy blood pressure [7, 8].

Therefore, it is not surprising that this is of particular concern for postmenopausal women, who have low levels of estrogens and are at a greater risk for developing obesity and cardiovascular-related health problems [9-12]. Because food and fluid intakes are, respectively, important parts of energy and body fluid homeostasis, understanding how estradiol decreases these ingestive behaviors is a crucial step in the discovery of interventions that can reduce morbidity and improve quality of life, especially for women.

The inhibitory effect of estrogens on food, water, and saline intake has been well studied for decades. In a variety of species, including rats, mice, and humans, food intake fluctuates across the estrous cycle with a significant decrease in food intake around the peri-ovulatory time period [3,13-16]. In rats, after ovariectomy baseline food intake rises and the cyclic change in intake is lost, revealing both a tonic and phasic inhibition in intake mediated by ovarian hormones [6]. Acute estradiol replacement restores the cyclic decrease in food intake [17]. Although progestin levels also fluctuate across the estrous cycle, treatment with progesterone alone has no effect on food intake nor does it modulate estradiol's ability to reduce intake. This suggests that estradiol is the primary ovarian hormone responsible for the observed effects [18-21]. In rats and mice, the decrease in food intake on estrus or after estradiol treatment is mediated by a selective decrease in meal size, often with a less reliable, and more variable, increase in meal number that fails to compensate for the reduction in intake [16, 22, 23]. Changes in meal size suggest that estradiol decreases food intake by increasing satiety signals [3]. Similar estrus-related changes in water and saline intake are also observed in female rats [5, 22, 24-26]. Again, intake increases after ovariectomy, and estradiol treatment, but not progesterone-treatment, decreases fluid intake [27-29]. Thus, there is reasonable evidence that estrogens are responsible for the ovarian effects on intake and that these effects generalize to several animal models.

Although estradiol clearly affects intake, its effects on food and fluid intake appear to occur independent of each other. An early study in ovariectomized (OVX) guinea pigs highlighted these independent effects of estradiol on ingestive behaviors [30]. In this series of experiments when food intake was restricted to $\sim 30 \%$ below ab libitum levels estradiol treatment only decreased water intake. In turn, when water intake was restricted, estradiol treatment only decreased food intake. Stronger evidence for this separability of estradiol's effects on fluid intake from any effect on feeding comes from studies using dipsogenic treatments that have minimal or no effect on food intake. For instance, administration of angiotensin II (AngII) causes rapid and robust drinking behavior without any acute effects on food intake, and estradiol decreases the drinking that occurs after AngII [25, 26]. Furthermore, we recently reported that larger doses of estradiol are necessary to reduce water intake in comparison to doses necessary to reduce food intake. This demonstrates that estradiol's anorexigenic effect can be observed without a simultaneous decrease in fluid intake [31]. Together these data suggest that separate mechanisms are involved in reducing intake of food and fluids. It is, however, possible that the apparent separability of the fluid and food intake effects is due to different dose-response curves for the different behaviors, rather than separate mechanisms controlling each. Further research is required to rule out 
this alternate explanation, and experiments addressing the issue are underway in our laboratory.

Fluid intake can be stimulated by reducing the volume of either the intracellular or extracellular space. Estradiol appears to selectively reduce fluid intake that is stimulated by extracellular dehydration [4]. This type of perturbation of fluid balance results in elevation of AngII, which leads to restorative ingestion of both water and saline [7]. Both water and saline intakes after AngII treatment are decreased on the day of estrus in intact female rats, and exogenous estradiol decreases AngII-stimulated intake in OVX rats [25, 26, 29, 32]. In addition to AngII treatment, other models of extracellular dehydration support the role of estrogens in controlling fluid intake. For instance, fluid intake stimulated by the $\beta$-adrenergic agonist isoproterenol varies across the estrous cycle, with the lowest intake observed during estrus [33], and estradiol treatment reduces the water and saline intakes normally stimulated by treatment with isoproterenol [28, 34, 35]. Furthermore, fluid intake stimulated by the diuretic furosemide, either alone or in combination with captopril (an inhibitor of the enzyme that generates AngII), is less robust on the day of estrus than when the treatments are given on diestrus. Consistent with the hypothesis that this is due to the elevated estradiol associated with estrus, estradiol treatment in OVX rats decreases intake normally stimulated by the diuretic with or without captopril [36, 37]. Contrary to estradiol's influence on extracellular dehydration, thirst stimulated by intracellular dehydration, which selectively increases water intake, is not reduced by estradiol. For example, water intake stimulated by hypertonic saline treatment does not change across the estrous cycle in intact rats nor is it influenced by estradiol-treatment in OVX rats [25, 34, 37, 38]. These results clearly demonstrate that estradiol has a strong effect on drinking, and that this effect is selective to drinking caused by extracellular dehydration.

A key step in generating a full understanding of the mechanism(s) by which estradiol decreases food and fluid intakes is to identify the estrogen receptor(s) involved in these processes. A complete understanding has been complicated by the existence of multiple estrogen receptor (ER) subtypes throughout the brain and their diverse cellular distribution. Specifically, ER subtypes are found in the cell nucleus, where they exert classical transcriptional effects, but are also found associated with the plasma membrane, where they act through signaling pathways with diverse effects. The remainder of this review will discuss the identified ER subtypes and will describe recent work aimed at identifying their roles in the controls of food and fluid intake in female rodents.

\section{ER subtypes and localization}

Until 1996 it was believed that only one ER existed. This protein, called ER, was thought to be exclusively found in the cell nucleus, where it is normally inhibited by heat shock proteins. When activated by estrogens, these heat shock proteins are released, allowing ER to dimerize, recruit coactivators/corepressors, and bind to estrogen response element sequences to initiate or repress gene expression $[39,40]$. This relatively simple picture of estrogen effects was first complicated by the discovery of a new nuclear ER named estrogen receptor beta $(\mathrm{ER} \beta)$; the original ER was renamed estrogen receptor alpha (ERa) [41, 42]. Although this finding added a new receptor that could respond to estrogens, ER $\beta$ was found 
to act similarly to ERa, and the picture was only slightly expanded to include this second receptor and the clear ability of the receptors to form heterodimers [42]. Although both receptor subtypes are found throughout the central nervous system, the discovery of ER $\beta$ revealed key differences between ERa and ER $\beta$ expression in areas of the brains that are involved in the regulation of food and fluid intakes (Figure 1). For example, the subfornical organ (SFO), a region critical for fluid intake, expresses ERa, but not ER $\beta$. The supraoptic nucleus (SON) and paraventricular nucleus (PVN), two areas also involved in regulating body fluid homeostasis, along with the dorsal raphe (DR), where the cell bodies of serotonin neurons involved in regulating food intake originate, express ER $\beta$, but not ERa [43]. Other brain regions, such as the nucleus of the solitary tract (NTS), lateral hypothalamus (LH), arcuate nucleus (Arc), anteroventral third ventricle region (AV3V), and medial preoptic area (mPOA), express both receptor subtypes [43].

Our understanding of estrogen effects was further complicated by studies revealing the diverse mechanisms downstream of ERs. One such mechanism involves effects on cell physiology that are too rapid to require changes in gene expression. Although these rapid electrophysiological effects were identified almost 40 years ago [44], the study and identification of membrane-associated ERs only started to gain attention towards the end of the 1990s. These studies, to date, identified three novel membrane-associated ERs, GPER-1, ER-X and Gq-mER. The first of these became relevant to the study of estrogen effects when it was discovered that orphan receptor GPR30 binds estradiol and other putative ERselective ligands without having any affinity for other steroid hormones [45, 46]. This orphan receptor was subsequently renamed G protein-coupled estrogen receptor 1 (GPER-1) because of its recognized actions through Gs and its classical heptahelical transmembrane structure. Similar to other Gs-coupled receptors, GPER-1 activates intracellular signaling through stimulation of adenylyl cyclase and G-protein-dependent release of membranetethered heparin bound epidermal growth factor [47]. Interestingly, GPER-1 is expressed in a number of nuclei involved in the controls of fluid and food intake. Specifically, GPER-1 mRNA has been detected in the LH, PVN, Arc and the NTS [48-50].

Immunohistochemistry studies have localized GPER-1 to neurons in the PVN and SON where it is often co-expressed with the hormone oxytocin [51], an important peptide in the control of fluid balance maintenance $[52,53]$. While the search for the endogenous ligand for GPER-1 was occurring, another membrane-associated ER was identified and named ER$X$. This receptor is embedded in caveolar-like microdomains where it can interact rapidly with kinases that activate a mitogen-activated protein kinase (MAPK) cascade. Interestingly, ER-X is expressed in the cortex in postnatal, but not adult, animals; however, it is reexpressed in the adult brain after injury by ischemic stroke [54]. Finally, Gq-mER is a membrane-associated G-protein coupled ER that has been extensively studied in hypothalamic tissue from guinea pigs and mice $[55,56]$. A selective ligand, STX, has been developed for this receptor which, along with estradiol, causes activation of PKC-PKA pathways that can be blocked by the antagonist ICI [57]. Although there are obvious functional effects of Gq-mER in the hypothalamus, a complete mapping of its expression has been limited because the receptor has yet to be cloned (for a comprehensive review of these receptors please see $[47,58-60])$. 
The discovery of the membrane-associated ER subtypes revealed incredible diversity in the means by which estrogens can affect cell function. This diversity became even more robust with more recent data demonstrating that both ERa and ER $\beta$ also can associate with the cell membrane and act as surface receptors [61, 62]. This membrane association occurs through the posttranslational palmitoylation of the ER and requires interactions with caveolin proteins that anchor the receptors to the cell membrane [63, 64]. Although surface ERa/ER $\beta$ can have rapid, non-genomic effects, membrane-associated ERa and membrane-associated ER $\beta$ can still influence gene transcription via CREB phosphorylation [65-67]. This mechanism of action, however, requires additional protein interactions. Specifically, there is a growing list of studies demonstrating that membrane-associated ERa and ER $\beta$ have no intrinsic ability to activate second messenger systems but use crosstalk with other membrane receptors to provide a means for intracellular signaling. Current evidence suggests that this is often accomplished by interactions with mGluR subtypes [65-69]. For example, in hippocampal neurons, membrane-associated ERa activates mGluR5 and subsequently increases CREB activation, but membrane-associated ERa can also decrease CREB activation by interacting with mGluR3 [66]. In the Arc, membrane-associated ERa stimulates mGluR1a-mediated $\mu$-opioid receptor internalization in the mPOA, and this internalization is critical for the expression of lordosis [67]. Additionally, mGluR1a antagonism in the Arc decreases the effect of $\mathrm{E} 2$ on lordosis in OVX rats [67]. Interactions between membrane-associated ERa/ER $\beta$ and mGluRs also have been shown in striatal neurons, hypothalamic astrocytes, and dorsal root ganglia neurons where they influence CREB activation or calcium influx $[65,68,69]$. These experiments have provided a crucial understanding of how ERa and ER $\beta$ have functional roles within the cell membrane in spite of an apparent lack of any direct association with intracellular signaling pathways. The diversity of ER actions is illustrated in Figure 2.

Based on the distributed expression of ER subtypes it should not be surprising that multiple nuclei involved in controlling food and water intake are areas sensitive to estradiol's anorexigenic and anti-dipsogenic effects. In the hindbrain, implants of estradiol benzoate over the caudal NTS reduce food intake in OVX rats [70]. In the midbrain, acute infusion of estradiol in the dorsal raphe nucleus reduce overnight food intake in OVX rats [71]. In the forebrain, there are multiple nuclei that have been implicated in mediating these actions of estradiol. Specifically, estradiol infusions into the Arc and mPOA reduce food intake [71, 72], and estradiol infusions into the AV3V and mPOA reduce AngII-stimulated water intake in OVX rats [38, 73]. Importantly, these responses seem to be anatomically selective because estradiol infusion into the ventromedial hypothalamus (VMH) of OVX rats does not change food or water intake [71, 73, 74], even though the VMH contains dense ER expression [43]. Figure 1 shows several structures that are involved in ingestive behaviors and highlights the ER subtype(s) expressed in each structure.

\section{Food Intake: The role of ER subtypes}

The majority of pharmacological and transgenic studies demonstrate that ERa is both sufficient and necessary for the anorexigenic effect of estradiol in female rats and mice. In OVX rats, acute or chronic treatment with the selective ERa agonist PPT reduces food intake by selectively reducing meal size $[75,76]$. A similar reduction in food intake is 
observed in OVX mice after PPT treatment [77]. Furthermore, selectively antagonizing ERa prevents exogenous estradiol's anorexigenic effect in OVX rats and the estrus-related decrease in food intake in intact female rats [78, 79]. Additional support for the role of ERa in mediating the anorexigenic effect of estradiol comes from studies in ERa knockout (aERKO) mice. aERKO mice have increased body weight and body adiposity which suggests a role for the receptor in mediating changes in food intake [80, 81]. Although baseline food intake does not differ in aERKO and wild-type mice, when aERKO mice are challenged with estradiol, a role for ERa in mediating an anorexegenic effect is revealed. Either chronic treatment with estradiol benzoate or acute treatment with PPT does not reduce food intake in OVX aERKO mice, even though these treatments are effective in wild-type mice [77, 82]. Furthermore, selective deletion of ERa from POMC neurons in the hypothalamus of wild-type female mice results in hyperphagia, demonstrating important anatomic localization for this effect [83]. Together these studies demonstrate that ERa is both necessary and sufficient for mediating estradiol's anorexigenic effect in rats and mice.

As previously discussed, ERa is traditionally described as a nuclear receptor, but it can also localize to the plasma membrane. This opens the question of whether nuclear ERa, membrane ERa, or both are involved in mediating estradiol's anorexigenic effect. We recently began addressing this issue using the OVX rat model. We measured food intake after central treatment with an estradiol-BSA conjugate; the BSA prevents the estradiol from entering the cell therefore it can only activate membrane-associated receptors. We found that overnight food intake was decreased after treatment with the estradiol-BSA conjugate [31]. This finding supports the hypothesis that membrane-associated ERs, presumably ERa, are involved in mediating the anorexigenic effect of estradiol. Ongoing research in our lab is aimed at identifying key brain areas involved in these effects and understanding how membrane receptor signaling influences food intake. Specifically, we are currently targeting the mPOA because, as discussed above, it is one area of the brain that is sensitive to both estradiol's anorexigenic and anti-dipsogenic effects. Furthermore, in an attempt to identify the relevant signaling pathways involved, we are testing for interactions between membraneassociated ERs and metabotropic glutamate receptors that may contribute to the anorexigenic effect of estradiol.

Although our studies in rats suggest that membrane-associated receptors play a role in ingestive effects of estrogens, recent transgenic mouse models suggest that although some aspects of energy homeostasis are mediated by membrane-associated ERs, the anorexigenic effects of estradiol are mediated only by nuclear receptors. Specifically, female mice that express a form of ERa that is unable to bind DNA (KIKO), thereby disrupting classical nuclear ERa signaling while leaving membrane ERa signaling intact, do not show the typical increase in body adiposity observed in traditional aERKO mice [84]. This finding suggests that membrane-associated ERa signaling is involved in energy homeostasis. On the other hand, no differences are found between KIKO and traditional aERKO mice in daily chow or high fat diet intake [84]. The lack of difference in intake is not surprising because daily chow intake in aERKO mice does not differ from wild-type mice [80, 82]. What is, perhaps, most surprising is that when the KIKO mice are OVX and challenged with estradiol, they show no change in food intake, suggesting that membrane-associated ERa signaling is not sufficient in mediating the anorexigenic effect of estradiol [85]. Reconciling 
these reports from transgenic mice with our data in rats will be important in understanding the role of membrane-associated ER signaling in the control of food intake. It is possible that species-specific differences exist and membrane-associated ERa is involved in mediating changes in food intake in rats but not mice. This explanation is probable because there are already important documented differences in the estrogenic control of food intake between the two species. For example hyperphagia contributes, at least in part, to the weight gain after ovariectomy in rats [86]; however, no post-ovariectomy hyperphagia is observed in mice. In mice the body weight gain is entirely attributed to a change in energy expenditure [87]. It is, however, also possible that our estradiol-BSA study activated other membrane-associated ERs that are sufficient to decrease food intake. This, however, seems unlikely based on the pharmacological studies demonstrating that ERa is necessary for the anorexigenic effect of estradiol. Nevertheless, further study is needed to reconcile the apparently discrepant findings and determine the precise receptor involvement in the observed effects in rats.

A role for the more recently identified membrane ERs, Gq-mER and GPER-1, in the control of food intake has gained support in recent years. Chronic activation of Gq-mER with the selective agonist STX decreases average daily food intake in OVX guinea pigs and more acute treatment with STX decreases $24 \mathrm{~h}$ food intake to a degree similar in magnitude to estradiol [88]. Interestingly, in OVX guinea pigs, both estradiol and STX significantly reduce meal number with no change in meal size [88], demonstrating an important species difference because, as mentioned above, in rats and mice this decrease is mediated by a change in meal size. Follow up studies have shown that the inhibitory effect of Gq-mER activation on food intake is not sex dependent, but occurs in male guinea pigs as well [89]. To our knowledge, however, no studies have examined the anorexgenic effect of Gq-mER in female rats. Therefore, it will be interesting to explore whether this receptor is sufficient to decrease food intake in other rodents or if this effect is limited to guinea pigs.

Although limited, a small number of reports describe studies using knockout mice to explore the role that membrane-associated ER GPER-1 has on food intake. One study showed no change in average daily food intake in GPER-1 KO mice compared to wildtype controls, but did find a disruption in the estrus-related change in food intake [90]. In addition, the anorexigenic effect of leptin and CCK were absent in GPER-1 KO female mice, but not male mice [90]. This data suggest a role of GPER-1 in mediating E2's anorexigenic effects in female mice. Again, we are not aware of any published reports examining the role of GPER-1 in food intake in female rats, but experiments on this topic using a pharmacological approach are underway in our laboratory. Preliminary results from these studies suggest only a minimal role of GPER-1 in controlling food intake in OVX rats, providing additional support to the hypothesis that ERa is the most critical receptor for the anorexigenic effect of estradiol in female rats.

There is little available support for a role of either ER-X or ER $\beta$ in contributing to a change in food intake in rodents. To our knowledge there are no reports which have examined the contribution of ER-X to the anorexigenic effect of estradiol. The expression pattern alone of ER-X, which is detected either early in development or after brain injury, rules out any significant involvement it might have in regulating food intake in healthy adults [54]. There 
have been, however, a number of studies examining the role of ER $\beta$ in the estrogenic control of food intake. Pharmacological studies in female rats show that acute or chronic activation of ER $\beta$ is not sufficient to decrease food intake $[75,76]$ and selective antagonism of ER $\beta$ does not prevent estradiol's inhibitory effect on food intake [79]. There are, however, two reports that suggest some support for a role of ER $\beta$ in the controls of food intake in females. In one report, antisense oligodeoxynuleotides directed against ER $\beta$, but not ERa, prevented a decrease in food intake following estradiol treatment in OVX rats [91]. A second study reported no change in food intake after estradiol treatment in OVX $\beta$ ERKO mice, suggesting the receptor is necessary for this effect [92]. It is unclear how to reconcile the data from these two studies with the numerous pharmacological and other knockout reports suggesting a minimal role of ER $\beta$ in mediating the anorexigenic effect of estradiol. Accordingly, the bulk of the evidence continues to point to the ERa subtype as the most critical for the regulation of feeding behavior.

\section{Water and Saline Intake: The Role of ER Subtypes}

In contrast to the plethora of research focused on understanding the role of ER subtypes in mediating changes in food intake, almost no research has focused on understanding which ER subtypes mediate changes in water and saline intake. To our knowledge, fluid intake measures have not been reported using any ER knockout mouse model, and fluid intake control by estrogens appears to be almost exclusively studied in the female rat. One recent study tested the hypothesis that estradiol can rapidly reduce water intake. Although this is not a direct test of which receptor subtypes are involved, understanding the timecourse of action can shed light into the properties of the receptors that contribute to estradiol's antidipsogenic effect. In this study, the authors reported no difference in short term (15 min-90 $\mathrm{min}$ ) water intake stimulated by isoproterenol in oil- and estradiol-treated OVX rats. The earliest observable effects of estradiol were not apparent until $24 \mathrm{~h}$ after treatment [93]. This suggests that transcriptional events are required for the decrease in fluid intake. Because nuclear receptors can influence gene expression directly, and membrane-associated receptors can influence gene expression indirectly, it is possible that any ER could be involved in mediating this change. Studies described above conducted by our laboratory using an estradiol-BSA compound provide some relevant information. The reduction of overnight water intake after treatment with the estradiol-BSA provides support for a role of membrane-associated ERs [31]. Furthermore, we performed licking microstructure analysis after rats were treated with estradiol or estradiol-BSA that provides an important test for differences between the effect of the membrane-only effect of the BSA compound and estradiol that will activate all ERs. These analyses revealed that the anti-dipsogenic effect of estradiol was mediated by a change in both burst number and burst size, suggesting respective changes in post-ingestive and orosensory aspects of water intake, but the decrease in water intake after estradiol-BSA treatment was mediated only by a change in postingestive signals. Together this suggests that both nuclear and membrane-associated ERs are involved in reducing fluid intake, but perhaps through different mechanisms. Ongoing research in our laboratory is aimed at understanding which ER subtypes are involved in the anti-dipsogenic and anti-natriorexigenic effects of estradiol. Specifically, we are using a variety of approaches to investigate the roles of ERa, ER $\beta$ and GPER- 1 in the control of 
water and saline intake in female rats. Our preliminary data support different roles for each of the three receptors in the control of fluid balance.

\section{Conclusions}

Estrogens have obvious effects on behavior and health, and regulation of food and fluid intakes is particularly critical for energy homeostasis and cardiovascular health. Therefore, understanding the role estrogens play in food and fluid intake could lead to better therapies to reduce morbidity and improve quality of life for postmenopausal women. This review has focused on previous studies examining the role of ERs in mediating estradiol's anorexigenic, anti-dipsogenic and anti-natriorexigenic effects. Although we have described a number of important studies, and noted some progress toward an understanding of the ways that estrogens affect intake, we believe that more than anything, our discussion shows a disappointing sparsity of studies on these questions, and highlights the many open questions that remain. Ongoing research in our laboratory is designed to address many of these open questions. Furthermore, a recent strategic plan by the National Institutes of Health which aims to increase research on women's health issues has set forth a number of goals, including: (1) increasing the study of sex and gender differences in basic biomedical and behavioral research, (2) incorporating findings of sex and gender differences into the design and application of new technologies, medical devices, and therapeutic drugs, and (3) employ innovative strategies to build a well-trained, diverse, and vigorous women's health research workforce [94]. We are cautiously optimistic that this plan will help attract more investigators to this area of research. In addition to this more direct translational relevance, studies of estrogens on food and fluid intake serve as an important basic model for understanding broader questions related to behavioral effects of steroid hormones.

\section{Acknowledgments}

Support: NIH grants HL-091911(DD) and DK-098841 (JS)

\section{References}

1. Danaei G, Ding EL, Mozaffarian D, Taylor B, Rehm J, Murray CJ, et al. The preventable causes of death in the United States: comparative risk assessment of dietary, lifestyle, and metabolic risk factors. PLoS medicine. 2009; 6:e1000058. [PubMed: 19399161]

2. Finucane MM, Stevens GA, Cowan MJ, Danaei G, Lin JK, Paciorek CJ, et al. National, regional, and global trends in body-mass index since 1980: systematic analysis of health examination surveys and epidemiological studies with 960 country-years and 9.1 million participants. Lancet. 2011; 377:557-67. [PubMed: 21295846]

3. Eckel LA. Estradiol: a rhythmic, inhibitory, indirect control of meal size. Physiology \& behavior. 2004; 82:35-41. [PubMed: 15234587]

4. Curtis KS. Estrogen and the central control of body fluid balance. Physiology \& behavior. 2009; 97:180-92. [PubMed: 19268483]

5. Tarttelin MF, Gorski RA. Variations in food and water intake in the normal and acyclic female rat. Physiology \& behavior. 1971; 7:847-52. [PubMed: 5167385]

6. Wade GN. Some effects of ovarian hormones on food intake and body weight in female rats. Journal of comparative and physiological psychology. 1975; 88:183-93. [PubMed: 1120795]

7. Daniels, D.; Fluharty, SJ. Neuroendocrinology of Body Fluid Homeostasis. In: Pfaff, DW.; APA; Etgen, AM.; Fahrbach, SE.; Rubin, RT., editors. Hormones Brain and Behavior. 2. San Diego: Academic Press; 2009. p. 259-88. 
8. Duffey KJ, Popkin BM. Energy density, portion size, and eating occasions: contributions to increased energy intake in the United States, 1977-2006. PLoS medicine. 2011; 8:e1001050. [PubMed: 21738451]

9. Go AS, Mozaffarian D, Roger VL, Benjamin EJ, Berry JD, Borden WB, et al. Executive summary: heart disease and stroke statistics--2013 update: a report from the American Heart Association. Circulation. 2013; 127:143-52. [PubMed: 23283859]

10. Yang XP, Reckelhoff JF. Estrogen, hormonal replacement therapy and cardiovascular disease. Current opinion in nephrology and hypertension. 2011; 20:133-8. [PubMed: 21178615]

11. Lovejoy JC, Champagne CM, de Jonge L, Xie H, Smith SR. Increased visceral fat and decreased energy expenditure during the menopausal transition. Int J Obes (Lond). 2008; 32:949-58. [PubMed: 18332882]

12. Toth MJ, Tchernof A, Sites CK, Poehlman ET. Menopause-related changes in body fat distribution. Annals of the New York Academy of Sciences. 2000; 904:502-6. [PubMed: 10865795]

13. Drewett RF. Oestrous and dioestrous components of the ovarian inhibition on hunger in the rat. Animal behaviour. 1973; 21:772-80. [PubMed: 4798198]

14. Gong EJ, Garrel D, Calloway DH. Menstrual cycle and voluntary food intake. The American journal of clinical nutrition. 1989; 49:252-8. [PubMed: 2916445]

15. Lyons PM, Truswell AS, Mira M, Vizzard J, Abraham SF. Reduction of food intake in the ovulatory phase of the menstrual cycle. The American journal of clinical nutrition. 1989; 49:11648. [PubMed: 2729155]

16. Petersen S. The temporal pattern of feeding over the oestrous cycle of the mouse. Animal behaviour. 1976; 24:939-55. [PubMed: 1034453]

17. Geary N, Asarian L. Cyclic estradiol treatment normalizes body weight and test meal size in ovariectomized rats. Physiology \& behavior. 1999; 67:141-7. [PubMed: 10463640]

18. Varma M, Chai JK, Meguid MM, Laviano A, Gleason JR, Yang ZJ, et al. Effect of estradiol and progesterone on daily rhythm in food intake and feeding patterns in Fischer rats. Physiology \& behavior. 1999; 68:99-107. [PubMed: 10627068]

19. Geary N, Trace D, McEwen B, Smith GP. Cyclic estradiol replacement increases the satiety effect of CCK-8 in ovariectomized rats. Physiology \& behavior. 1994; 56:281-9. [PubMed: 7938239]

20. Gray JM, Wade GN. Food intake, body weight, and adiposity in female rats: actions and interactions of progestins and antiestrogens. The American journal of physiology. 1981; 240:E474-81. [PubMed: 7195153]

21. Schwartz SM, Wade GN. Effects of estradiol and progesterone on food intake, body weight, and carcass adiposity in weanling rats. The American journal of physiology. 1981; 240:E499-503. [PubMed: 7235006]

22. Eckel LA, Houpt TA, Geary N. Spontaneous meal patterns in female rats with and without access to running wheels. Physiology \& behavior. 2000; 70:397-405. [PubMed: 11006440]

23. Blaustein JD, Wade GN. Ovarian influences on the meal patterns of female rats. Physiology \& behavior. 1976; 17:201-8. [PubMed: 1033580]

24. Antunes Rodrigues J, Covian MR. Hypothalamic Control of Sodium Chloride and Water Intake. Acta physiologica latino americana. 1963; 13:94-100. [PubMed: 14098053]

25. Findlay AL, Fitzsimons JT, Kucharczyk J. Dependence of spontaneous and angiotensin-induced drinking in the rat upon the oestrous cycle and ovarian hormones. The Journal of endocrinology. 1979; 82:215-25. [PubMed: 573776]

26. Danielsen J, Buggy J. Depression of ad lib and angiotensin-induced sodium intake at oestrus. Brain research bulletin. 1980; 5:501-4. [PubMed: 7191763]

27. Spiteri NJ, Drewett RF, Padel U. Behavioral effects of ethynyl estrogens in the female rat. Physiology \& behavior. 1980; 25:409-15. [PubMed: 7443810]

28. Thrasher TN, Fregly MJ. Responsiveness to various dipsogenic stimuli in rats treated chronically with norethynodrel, ethinyl estradiol and both combined. The Journal of pharmacology and experimental therapeutics. 1977; 201:84-91. [PubMed: 850148] 
29. Kisley LR, Sakai RR, Ma LY, Fluharty SJ. Ovarian steroid regulation of angiotensin II-induced water intake in the rat. The American journal of physiology. 1999; 276:R90-6. [PubMed: 9887181]

30. Czaja JA, Butera PC, McCaffrey TA. Independent effects of estradiol on water and food intake. Behavioral neuroscience. 1983; 97:210-20. [PubMed: 6849684]

31. Santollo J, Marshall A, Daniels D. Activation of membrane-associated estrogen receptors decreases food and water intake in ovariectomized rats. Endocrinology. 2013; 154:320-9. [PubMed: 23183173]

32. Fregly MJ, Thrasher TN. Attenuation of angiotensin-induced water intake in estrogen-treated rats. Pharmacology, biochemistry, and behavior. 1978; 9:509-14.

33. Kucharczyk J. Localization of central nervous system structures mediating extracellular thirst in the female rat. The Journal of endocrinology. 1984; 100:183-8. [PubMed: 6537965]

34. Krause EG, Curtis KS, Davis LM, Stowe JR, Contreras RJ. Estrogen influences stimulated water intake by ovariectomized female rats. Physiology \& behavior. 2003; 79:267-74. [PubMed: 12834798]

35. Jones AB, Curtis KS. Differential effects of estradiol on drinking by ovariectomized rats in response to hypertonic $\mathrm{NaCl}$ or isoproterenol: Implications for hyper- vs. hypo-osmotic stimuli for water intake. Physiology \& behavior. 2009; 98:421-6. [PubMed: 19616566]

36. Dalmasso C, Amigone JL, Vivas L. Serotonergic system involvement in the inhibitory action of estrogen on induced sodium appetite in female rats. Physiology \& behavior. 2011; 104:398-407. [PubMed: 21554894]

37. Mecawi AS, Lepletier A, Araujo IG, Fonseca FV, Reis LC. Oestrogenic influence on brain AT1 receptor signalling on the thirst and sodium appetite in osmotically stimulated and sodiumdepleted female rats. Experimental physiology. 2008; 93:1002-10. [PubMed: 18441334]

38. Jonklaas J, Buggy J. Angiotensin-estrogen interaction in female brain reduces drinking and pressor responses. The American journal of physiology. 1984; 247:R167-72. [PubMed: 6742227]

39. O'Lone R, Frith MC, Karlsson EK, Hansen U. Genomic targets of nuclear estrogen receptors. Mol Endocrinol. 2004; 18:1859-75. [PubMed: 15031323]

40. Heldring N, Pike A, Andersson S, Matthews J, Cheng G, Hartman J, et al. Estrogen receptors: how do they signal and what are their targets. Physiological reviews. 2007; 87:905-31. [PubMed: 17615392]

41. Kuiper GG, Enmark E, Pelto-Huikko M, Nilsson S, Gustafsson JA. Cloning of a novel receptor expressed in rat prostate and ovary. Proceedings of the National Academy of Sciences of the United States of America. 1996; 93:5925-30. [PubMed: 8650195]

42. Kuiper GG, Gustafsson JA. The novel estrogen receptor-beta subtype: potential role in the celland promoter-specific actions of estrogens and anti-estrogens. FEBS letters. 1997; 410:87-90. [PubMed: 9247129]

43. Shughrue PJ, Lane MV, Merchenthaler I. Comparative distribution of estrogen receptor-alpha and -beta mRNA in the rat central nervous system. The Journal of comparative neurology. 1997; 388:507-25. [PubMed: 9388012]

44. Kelly MJ, Moss RL, Dudley CA. Differential sensitivity of preoptic-septal neurons to microelectrophoresed estrogen during the estrous cycle. Brain research. 1976; 114:152-7. [PubMed: 986858]

45. Revankar CM, Cimino DF, Sklar LA, Arterburn JB, Prossnitz ER. A transmembrane intracellular estrogen receptor mediates rapid cell signaling. Science. 2005; 307:1625-30. [PubMed: 15705806]

46. Thomas P, Pang Y, Filardo EJ, Dong J. Identity of an estrogen membrane receptor coupled to a G protein in human breast cancer cells. Endocrinology. 2005; 146:624-32. [PubMed: 15539556]

47. Srivastava DP, Evans PD. G-protein oestrogen receptor 1: trials and tribulations of a membrane oestrogen receptor. Journal of neuroendocrinology. 2013; 25:1219-30. [PubMed: 23822769]

48. Brailoiu E, Dun SL, Brailoiu GC, Mizuo K, Sklar LA, Oprea TI, et al. Distribution and characterization of estrogen receptor $\mathrm{G}$ protein-coupled receptor 30 in the rat central nervous system. The Journal of endocrinology. 2007; 193:311-21. [PubMed: 17470522] 
49. Spary EJ, Maqbool A, Batten TF. Oestrogen receptors in the central nervous system and evidence for their role in the control of cardiovascular function. Journal of chemical neuroanatomy. 2009; 38:185-96. [PubMed: 19505570]

50. Spary EJ, Chapman SE, Sinfield JK, Maqbool A, Kaye J, Batten TF. Novel G protein-coupled oestrogen receptor GPR30 shows changes in mRNA expression in the rat brain over the oestrous cycle. Neuro-Signals. 2013; 21:14-27. [PubMed: 22378360]

51. Sakamoto H, Matsuda K, Hosokawa K, Nishi M, Morris JF, Prossnitz ER, et al. Expression of G protein-coupled receptor-30, a G protein-coupled membrane estrogen receptor, in oxytocin neurons of the rat paraventricular and supraoptic nuclei. Endocrinology. 2007; 148:5842-50. [PubMed: 17872373]

52. Blackburn RE, Demko AD, Hoffman GE, Stricker EM, Verbalis JG. Central oxytocin inhibition of angiotensin-induced salt appetite in rats. The American journal of physiology. 1992; 263:R134753. [PubMed: 1336319]

53. Blackburn RE, Samson WK, Fulton RJ, Stricker EM, Verbalis JG. Central oxytocin inhibition of salt appetite in rats: evidence for differential sensing of plasma sodium and osmolality. Proceedings of the National Academy of Sciences of the United States of America. 1993; 90:10380-4. [PubMed: 8234302]

54. Toran-Allerand CD, Guan X, MacLusky NJ, Horvath TL, Diano S, Singh M, et al. ER-X: a novel, plasma membrane-associated, putative estrogen receptor that is regulated during development and after ischemic brain injury. The Journal of neuroscience: the official journal of the Society for Neuroscience. 2002; 22:8391-401. [PubMed: 12351713]

55. Lagrange AH, Ronnekleiv OK, Kelly MJ. Modulation of G protein-coupled receptors by an estrogen receptor that activates protein kinase A. Molecular pharmacology. 1997; 51:605-12. [PubMed: 9106625]

56. Qiu J, Bosch MA, Tobias SC, Grandy DK, Scanlan TS, Ronnekleiv OK, et al. Rapid signaling of estrogen in hypothalamic neurons involves a novel G-protein-coupled estrogen receptor that activates protein kinase C. The Journal of neuroscience: the official journal of the Society for Neuroscience. 2003; 23:9529-40. [PubMed: 14573532]

57. Qiu J, Bosch MA, Tobias SC, Krust A, Graham SM, Murphy SJ, et al. A G-protein-coupled estrogen receptor is involved in hypothalamic control of energy homeostasis. The Journal of neuroscience: the official journal of the Society for Neuroscience. 2006; 26:5649-55. [PubMed: 16723521]

58. Langer G, Bader B, Meoli L, Isensee J, Delbeck M, Noppinger PR, et al. A critical review of fundamental controversies in the field of GPR30 research. Steroids. 2010; 75:603-10. [PubMed: 20034504]

59. Roepke TA, Qiu J, Bosch MA, Ronnekleiv OK, Kelly MJ. Cross-talk between membrane-initiated and nuclear-initiated oestrogen signalling in the hypothalamus. Journal of neuroendocrinology. 2009; 21:263-70. [PubMed: 19187465]

60. Toran-Allerand CD. Estrogen and the brain: beyond ER-alpha, ER-beta, and 17beta-estradiol. Annals of the New York Academy of Sciences. 2005; 1052:136-44. [PubMed: 16024756]

61. Pappas TC, Gametchu B, Watson CS. Membrane estrogen receptors identified by multiple antibody labeling and impeded-ligand binding. FASEB journal: official publication of the Federation of American Societies for Experimental Biology. 1995; 9:404-10. [PubMed: 7896011]

62. Gorosito SV, Lorenzo AG, Cambiasso MJ. Estrogen receptor alpha is expressed on the cell-surface of embryonic hypothalamic neurons. Neuroscience. 2008; 154:1173-7. [PubMed: 18556135]

63. Boulware MI, Kordasiewicz H, Mermelstein PG. Caveolin proteins are essential for distinct effects of membrane estrogen receptors in neurons. The Journal of neuroscience: the official journal of the Society for Neuroscience. 2007; 27:9941-50. [PubMed: 17855608]

64. Acconcia F, Ascenzi P, Bocedi A, Spisni E, Tomasi V, Trentalance A, et al. Palmitoylationdependent estrogen receptor alpha membrane localization: regulation by 17 beta-estradiol. Molecular biology of the cell. 2005; 16:231-7. [PubMed: 15496458]

65. Grove-Strawser D, Boulware MI, Mermelstein PG. Membrane estrogen receptors activate the metabotropic glutamate receptors mGluR5 and mGluR3 to bidirectionally regulate CREB 
phosphorylation in female rat striatal neurons. Neuroscience. 2010; 170:1045-55. [PubMed: 20709161]

66. Boulware MI, Weick JP, Becklund BR, Kuo SP, Groth RD, Mermelstein PG. Estradiol activates group I and II metabotropic glutamate receptor signaling, leading to opposing influences on cAMP response element-binding protein. The Journal of neuroscience: the official journal of the Society for Neuroscience. 2005; 25:5066-78. [PubMed: 15901789]

67. Dewing P, Boulware MI, Sinchak K, Christensen A, Mermelstein PG, Micevych P. Membrane estrogen receptor-alpha interactions with metabotropic glutamate receptor 1a modulate female sexual receptivity in rats. The Journal of neuroscience: the official journal of the Society for Neuroscience. 2007; 27:9294-300. [PubMed: 17728443]

68. Chaban V, Li J, McDonald JS, Rapkin A, Micevych P. Estradiol attenuates the adenosine triphosphate-induced increase of intracellular calcium through group II metabotropic glutamate receptors in rat dorsal root ganglion neurons. Journal of neuroscience research. 2011; 89:1707-10. [PubMed: 21793040]

69. Kuo J, Hariri OR, Bondar G, Ogi J, Micevych P. Membrane estrogen receptor-alpha interacts with metabotropic glutamate receptor type 1a to mobilize intracellular calcium in hypothalamic astrocytes. Endocrinology. 2009; 150:1369-76. [PubMed: 18948402]

70. Thammacharoen S, Lutz TA, Geary N, Asarian L. Hindbrain administration of estradiol inhibits feeding and activates estrogen receptor-alpha-expressing cells in the nucleus tractus solitarius of ovariectomized rats. Endocrinology. 2008; 149:1609-17. [PubMed: 18096668]

71. Santollo J, Torregrossa AM, Eckel LA. Estradiol acts in the medial preoptic area, arcuate nucleus, and dorsal raphe nucleus to reduce food intake in ovariectomized rats. Hormones and behavior. 2011; 60:86-93. [PubMed: 21439964]

72. Dagnault A, Richard D. Involvement of the medial preoptic area in the anorectic action of estrogens. The American journal of physiology. 1997; 272:R311-7. [PubMed: 9039023]

73. Jonklaas J, Buggy J. Angiotensin-estrogen central interaction: localization and mechanism. Brain research. 1985; 326:239-49. [PubMed: 3971153]

74. Butera PC, Beikirch RJ. Central implants of diluted estradiol: independent effects on ingestive and reproductive behaviors of ovariectomized rats. Brain research. 1989; 491:266-73. [PubMed: 2765887]

75. Santollo J, Wiley MD, Eckel LA. Acute activation of ER alpha decreases food intake, meal size, and body weight in ovariectomized rats. American journal of physiology. Regulatory, integrative and comparative physiology. 2007; 293:R2194-201.

76. Roesch DM. Effects of selective estrogen receptor agonists on food intake and body weight gain in rats. Physiology \& behavior. 2006; 87:39-44. [PubMed: 16181647]

77. Thammacharoen S, Geary N, Lutz TA, Ogawa S, Asarian L. Divergent effects of estradiol and the estrogen receptor-alpha agonist PPT on eating and activation of PVN CRH neurons in ovariectomized rats and mice. Brain research. 2009; 1268:88-96. [PubMed: 19281799]

78. Santollo J, Eckel LA. Effect of a putative ERalpha antagonist, MPP, on food intake in cycling and ovariectomized rats. Physiology \& behavior. 2009; 97:193-8. [PubMed: 19254732]

79. Santollo J, Katzenellenbogen BS, Katzenellenbogen JA, Eckel LA. Activation of ERalpha is necessary for estradiol's anorexigenic effect in female rats. Hormones and behavior. 2010; 58:872-7. [PubMed: 20807534]

80. Heine PA, Taylor JA, Iwamoto GA, Lubahn DB, Cooke PS. Increased adipose tissue in male and female estrogen receptor-alpha knockout mice. Proceedings of the National Academy of Sciences of the United States of America. 2000; 97:12729-34. [PubMed: 11070086]

81. Ohlsson C, Hellberg N, Parini P, Vidal O, Bohlooly YM, Rudling M, et al. Obesity and disturbed lipoprotein profile in estrogen receptor-alpha-deficient male mice. Biochemical and biophysical research communications. 2000; 278:640-5. [PubMed: 11095962]

82. Geary N, Asarian L, Korach KS, Pfaff DW, Ogawa S. Deficits in E2-dependent control of feeding, weight gain, and cholecystokinin satiation in ER-alpha null mice. Endocrinology. 2001; 142:47517. [PubMed: 11606440] 
83. Xu Y, Nedungadi TP, Zhu L, Sobhani N, Irani BG, Davis KE, et al. Distinct hypothalamic neurons mediate estrogenic effects on energy homeostasis and reproduction. Cell metabolism. 2011; 14:453-65. [PubMed: 21982706]

84. Park CJ, Zhao Z, Glidewell-Kenney C, Lazic M, Chambon P, Krust A, et al. Genetic rescue of nonclassical ERalpha signaling normalizes energy balance in obese Eralpha-null mutant mice. The Journal of clinical investigation. 2011; 121:604-12. [PubMed: 21245576]

85. Mamounis KJ, Yang JA, Yasrebi A, Roepke TA. Estrogen response element-independent signaling partially restores post-ovariectomy body weight gain but is not sufficient for 17beta-estradiol's control of energy homeostasis. Steroids. 2014; 81:88-98. [PubMed: 24252383]

86. Mueller K, Hsiao S. Estrus- and ovariectomy-induced body weight changes: evidence for two estrogenic mechanisms. Journal of comparative and physiological psychology. 1980; 94:1126-34. [PubMed: 7193690]

87. Witte MM, Resuehr D, Chandler AR, Mehle AK, Overton JM. Female mice and rats exhibit species-specific metabolic and behavioral responses to ovariectomy. General and comparative endocrinology. 2010; 166:520-8. [PubMed: 20067798]

88. Roepke TA, Bosch MA, Rick EA, Lee B, Wagner EJ, Seidlova-Wuttke D, et al. Contribution of a membrane estrogen receptor to the estrogenic regulation of body temperature and energy homeostasis. Endocrinology. 2010; 151:4926-37. [PubMed: 20685867]

89. Smith AW, Bosch MA, Wagner EJ, Ronnekleiv OK, Kelly MJ. The membrane estrogen receptor ligand STX rapidly enhances GABAergic signaling in NPY/AgRP neurons: role in mediating the anorexigenic effects of 17beta-estradiol. American journal of physiology. Endocrinology and metabolism. 2013; 305:E632-40. [PubMed: 23820624]

90. Davis KE, Carstens EJ, Irani BG, Gent LM, Hahner LM, Clegg DJ. Sexually dimorphic role of G protein-coupled estrogen receptor (GPER) in modulating energy homeostasis. Hormones and behavior. 2014; 66:196-207. [PubMed: 24560890]

91. Liang YQ, Akishita M, Kim S, Ako J, Hashimoto M, Iijima K, et al. Estrogen receptor beta is involved in the anorectic action of estrogen. International journal of obesity and related metabolic disorders: journal of the International Association for the Study of Obesity. 2002; 26:1103-9.

92. Naaz A, Zakroczymski M, Heine P, Taylor J, Saunders P, Lubahn D, et al. Effect of ovariectomy on adipose tissue of mice in the absence of estrogen receptor alpha (ERalpha): a potential role for estrogen receptor beta (ERbeta). Hormone and metabolic research $=$ Hormon- und Stoffwechselforschung $=$ Hormones et metabolisme. 2002; 34:758-63. [PubMed: 12660895]

93. Graves NS, Hayes H, Fan L, Curtis KS. Time course of behavioral, physiological, and morphological changes after estradiol treatment of ovariectomized rats. Physiology \& behavior. 2011; 103:261-7. [PubMed: 21324332]

94. Pinn VW, Clayton JA, Begg L, Sass SE. Public partnerships for a vision for women's health research in 2020. J Womens Health (Larchmt). 2010; 19:1603-7. [PubMed: 20815755] 


\section{Highlights}

- This review focuses on estrogen effects on ingestive behaviors

- Estrogens affect intake through several receptor subtypes

- The relevant estrogen receptors are found in several cellular locations

- Estrogens affect intake by actions at several brain areas

- Work from our laboratory has helped identify relevant estrogen receptor subtypes 


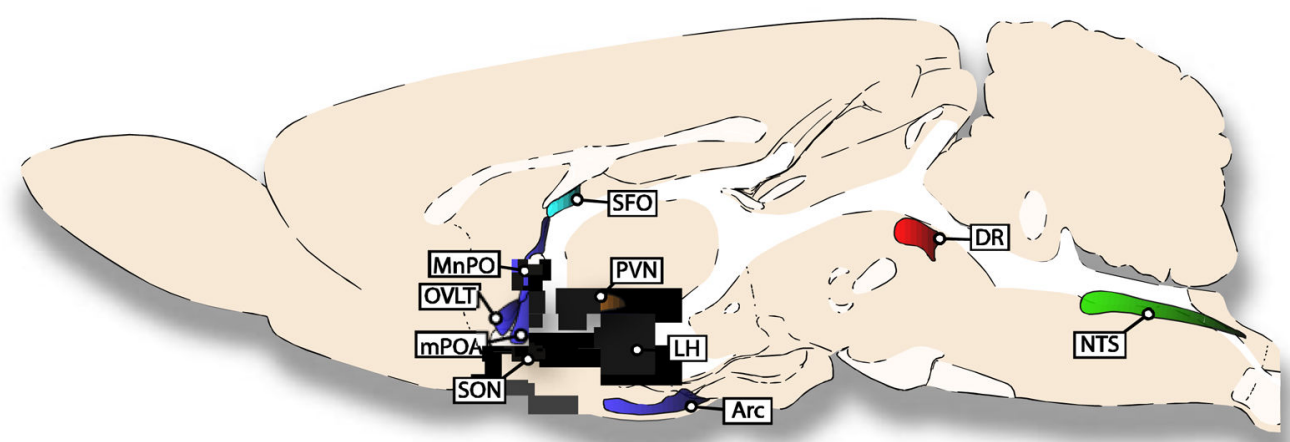

Figure 1.

Select brain structures that express ER subtypes and are involved in the effect of estrogens on ingestive behaviors. The ER subtype mRNA expressed in each area of rat brain is indicated by the color of the structure. SFO only expresses ERa (blue), whereas ER $\beta$ is the only ER subtype found in the DR (red). The MnPO, OVLT, mPOA, LH and ARC express both ERa and ER $\beta$ (purple). ER $\beta$ and GPER-1 are expressed in the PVN and SON (orange). ERa, ER $\beta$ and GPER-1 are expressed in the NTS (green). 


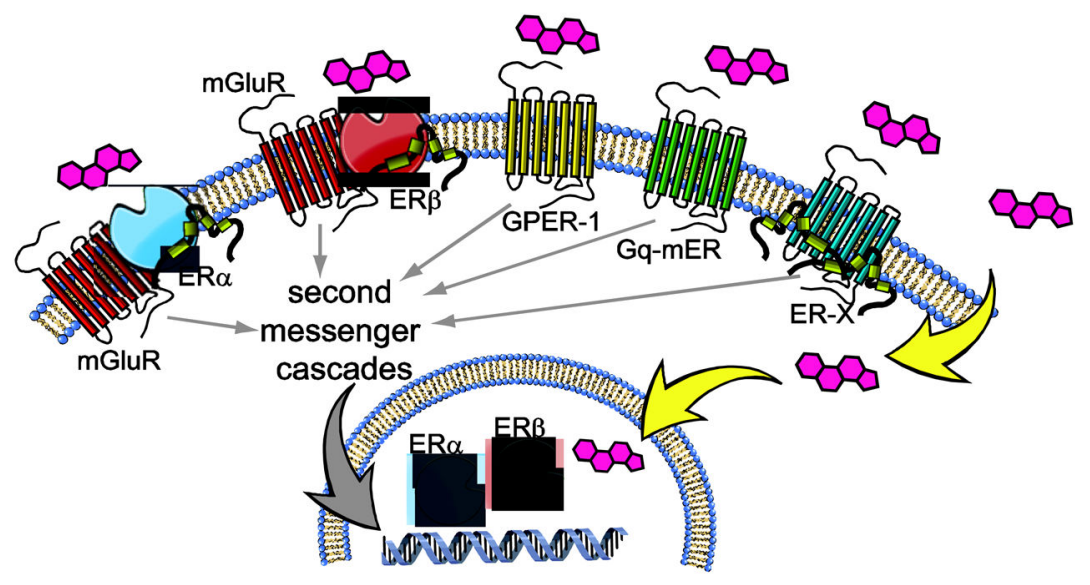

Figure 2.

Estrogens act through a diverse set of receptor subtypes. The ERa and ER $\beta$ subtypes are found in the nucleus of the cell, where they respond to estrogens to alter gene expression. After posttranslational modification, both ERa and ER $\beta$ are found associated with the plasma membrane, where they form a complex that includes caveolin and mGluR subtypes. Estrogens can also act at membrane-associated GPER-1, Gq-mER, and ER-X receptor subtypes, the latter of which is found embedded in caveolar-like microdomains. The membrane-associated receptors are able to exert rapid effects by interactions with ion channels, and slower effects through second messenger cascades that affect transcription. 